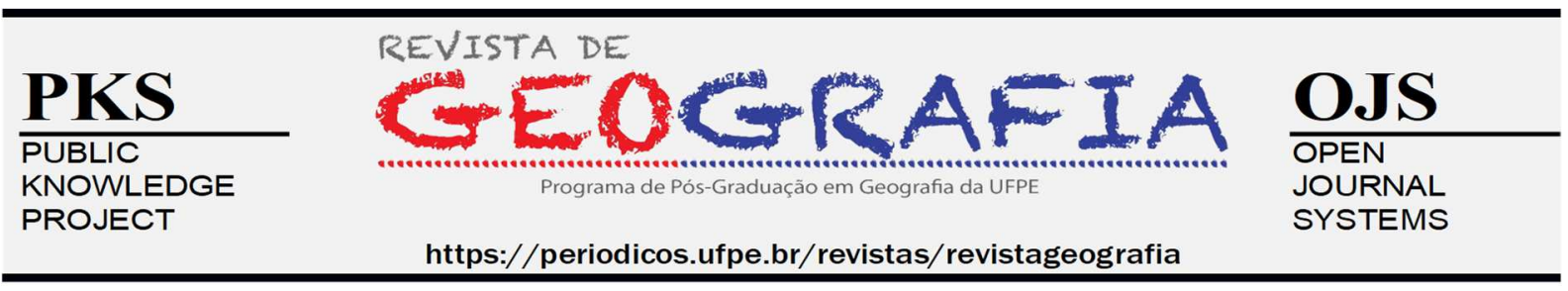

\title{
DOAÇÃO DE TERRAS NO SERTÃO DE ALAGOAS E A FORMAÇÃO DO TERRITÓRIO RELIGIOSO DO MUNICÍPIO DE MATA GRANDE
}

\author{
Magda Campos de Lima ${ }^{1}$ \\ ${ }^{1}$ Programa de Pós-Graduação em Geografia, Universidade Federal de Alagoas - UFAL, E-mail: magdajulia- \\ @ hotmail.com, ORCID: http://orcid.org/0000-0002-4680-1060
}

Artigo recebido em 01/06/2020 e aceito em 05/05/2021

\begin{abstract}
RESUMO
O território alagoano, desde sua gênese, foi formado através da distribuição de parte das terras chamadas de sesmarias. Esta pesquisa busca entender a motivação da doação de terras para a Igreja Católica, a formação e desenvolvimento do povoamento de Mata Grande em Alagoas. Um casal morador das Matas de Santa Cruz, motivados pela devoção, doou terras para o patrimônio de Nossa Senhora da Conceição, no dia 20 de junho de 1791, com a incumbência de ser construída uma capela. A pesquisa bibliográfica e documental descreve as características das doações de terras e da formação do território matagrandense. Quanto ao caráter documental da investigação, os documentos usados na pesquisa foram os arquivos da Paróquia Nossa Senhora da Conceição em Mata Grande, através dessas fontes comprobatórias foi possível que os fatos ocorridos há mais de duzentos anos fossem comprovados com maior veracidade e segurança. A demora da paróquia em demarcar e fiscalizar as terras doadas permitiu, a ocupação e a venda das terras de forma irregular e ocasionou alguns transtornos dentro da comunidade. A igreja tem a posse das terras apenas no sentido simbólico, caso necessite das próprias terras, terá que comprar ou recebe-lá como uma doação dos atuais ocupantes.
\end{abstract}

Palavras-chave: doação de terras; território religioso; Alagoas.

\section{DONATION OF LAND IN THE SERTÃO OF ALAGOAS AND THE FORMATION OF RELIGIOUS TERRITORY IN THE MUNICIPALITY OF MATA GRANDE}

\begin{abstract}
The territory of Alagoas, since its genesis, was formed through the distribution of part of the land called sesmarias. This research seeks to understand the motivation of land donation to the Catholic Church, the formation and development of the settlement of Mata Grande in Alagoas. A couple living in Matas de Santa Cruz, motivated by devotion, donated land to the patrimony of Nossa Senhora da Conceição, on June 20, 1791, with the task of building a chapel. The bibliographical and documental research describes the characteristics of land donations and the formation of the Matagrandense territory. As for the documentary nature of the investigation, the documents used in the research were the archives of the Nossa Senhora da Conceição Parish in Mata Grande, through these supporting sources it was possible that the facts that occurred more than two hundred years ago were proven with greater veracity and security. The parish's delay in demarcating and inspecting the donated lands allowed the illegal occupation and sale of lands and caused some disturbances within the community.
\end{abstract}


The church owns the land only in the symbolic sense, if it needs the land itself, it will have to buy it or receive it as a donation from the current occupants.

Keywords: land donation. religious territory. Alagoas.

\title{
DONACIÓN DE TERRENOS EN EL SERTÃO DE ALAGOAS Y FORMACIÓN DEL TERRITORIO RELIGIOSO DEL MUNICIPIO DE MATA GRANDE
}

\begin{abstract}
RESUMEN
El territorio de Alagoas, desde su génesis, se formó mediante la distribución de una parte de la tierra denominada sesmarias. Esta investigación busca comprender la motivación de la donación de tierras a la Iglesia Católica, la formación y desarrollo del asentamiento de Mata Grande en Alagoas. Un matrimonio residente en Matas de Santa Cruz, motivado por la devoción, donó un terreno al patrimonio de Nossa Senhora da Conceição, el 20 de junio de 1791, con la tarea de construir una capilla. La investigación bibliográfica y documental describe las características de las donaciones de tierras y la formación del territorio Matagrandense. En cuanto al carácter documental de la investigación, los documentos utilizados en la investigación fueron los archivos de la Parroquia Nossa Senhora da Conceição en Mata Grande, a través de estas fuentes de apoyo fue posible que los hechos ocurridos hace más de doscientos años fueran probados con mayor veracidad y seguridad. La demora de la parroquia en demarcar e inspeccionar las tierras donadas permitió la ocupación y venta ilegal de tierras y provocó algunos disturbios dentro de la comunidad. La iglesia posee la tierra solo en el sentido simbólico, si necesita la tierra en sí, tendrá que comprarla o recibirla como una donación de los ocupantes actuales.
\end{abstract}

Palabras clave: donación de tierras. territorio religioso. Alagoas.

\section{INTRODUÇÃO}

O território da futura Alagoas era integrada a capitania hereditária de Pernambuco instituída por Dom João III através do sistema de capitanias hereditárias e administrada por Duarte Coelho. Antes de Alagoas conseguir a emancipação de Pernambuco em 1817, as práticas das doações de terras possibilitaram a ocupação dos territórios alagoanos. Desde sua gênese, a ocupação do território e formação da sociedade alagoana foi iniciada pela distribuição das sesmarias, da atividade agrícola e principalmente do cultivo da cana de açúcar - principal base da sua economia, e a instalação dos currais de gado expandiu a ocupação para o Sertão.

Também era um costume dos portugueses doar terras para a construção de igrejas, e esse costume acabou sendo adotado pelos sesmeiros. Os administradores de grandes extensões de terras eram denominados de sesmeiros, e que doavam a parte da terra que não 
era utilizada no cultivo. Como mencionado, a doação de terras servia para a construção de igrejas, demonstrando um ato de devoção aos santos da religião oficial da coroa portuguesa e assim os praticantes da religião católica teriam mais chances de aceitação na sociedade. A presença da Igreja Católica podia trazer outros benefícios, como assegurar a ocupação e controle do território, ajudar na arrecadação de tributos para Fazenda Real custear as despesas dos administradores e as ações missionárias apaziguavam os conflitos.

A formação e desenvolvimento do território de Mata Grande em Alagoas ocorreram através da doação de terras para a Igreja Católica. Tendo em vista a prática das doações de terras, este estudo buscou compreender que motivação levou o casal Francisco Gonçalves Teixeira e sua esposa Luiza Maria a doar terras da sesmaria Mata Grande para o patrimônio da igreja. No território matagrandense ocorreram vários desmembramentos, o que levou a esse estudo identificar a causa que provocou a perda de grande parte do território paroquial e oficializou a emancipação dos novos municípios. Além disso, verificar como o descuido dos administradores da igreja em demarcar os limites das terras, o desaparecimento de documentos e as ocupações irregulares podem ter ocasionado situações conflituosas entre a igreja e a comunidade.

A sesmaria Mata Grande em Alagoas no passado teve um papel importante na consolidação do território sertanejo. Assim como ocorreu em Mata Grande, a doação de terras para a construção de igrejas era algo comum e o resultado dessa atitude ocasionou na ocupação de territórios e efetivou a criação de municípios. Em Alagoas, existem poucas pesquisas que relatam sobre as doações de terras para a igreja e a ocupação do território sertanejo. Diante disso, esse estudo é importante para a comunidade acadêmica e a sociedade em geral, pois proporciona diversos conhecimentos sobre o sertão alagoano, sendo necessário o resgate e a visibilidade da sua geo-historiografia que é pouco valorizada e divulgada.

Esta pesquisa bibliográfica e documental descreve as características do fenômeno das doações de terras e da formação do território matagrandense. Este contexto fundamenta-se em autores como: Andrade (2011), Carvalho (2016) Corrêa (2011), Curvelo (2011), Diégues júnior (2012), Herculano; Santos (2011), Lira (2007), Rosendahl (1996,2013), Madeira; Sampaio (2011), Verçosa (2006). Quanto ao caráter documental da investigação, os 
documentos usados na pesquisa foram os arquivos da Paróquia Nossa Senhora da Conceição de Mata Grande (AL).

Os dados e materiais permitem ao pesquisador ter fontes comprobatórias que comprovam com maior veracidade e segurança, os fatos ocorridos no passado. O que para Gil (2002, p.46) "nesta categoria estão os documentos conservados em arquivos de órgãos públicos e instituições privadas, tais como associações científicas, igrejas, etc”. No que compreende este trabalho, nas próximas seções abordaremos os primórdios da ocupação do território alagoano, a distribuição e exploração do território sertanejo; a doação de terras para o patrimônio da Igreja Católica; também iremos conhecer os desmembramentos ocorridos na Paróquia de Mata Grande; os limites do patrimônio paroquial de Mata Grande (AL); e por fim, as considerações finais.

\section{OS PRIMÓRDIOS DA OCUPAÇÃO DO TERRITÓRIO ALAGOANO}

No primeiro momento, Portugal não estava interessado na colonização do Brasil, e por conta da demora na ocupação dos territórios. Como cita Verçosa (2006, p. 25), "o atual Estado de Alagoas, a extensão das terras que foram produtos dos descobrimentos, até meados do século XVI, o território livre para a cobiça de navegadores não veio a ser efetivamente ocupado, a não ser a partir de então". Até ser efetivado como território alagoano, passando mais de dois séculos para os invasores portugueses ocuparem essas terras. Por conta dessa lentidão, os portugueses deram espaço e tempo suficiente para que os franceses pudessem se fixar no litoral.

A partir do instante em que Portugal percebeu que poderia perder o território para outros países, tratou de buscar garantir a posse das terras, com o sistema político de capitanias hereditárias. Segundo Carvalho (2016, p.11) "nos séculos XVI e XVII, antes de seu primeiro passo rumo à autonomia, o território foi sendo desenhado pelos movimentos de disputa e ocupação-como a luta contra a presença francesa no litoral". Além dos conflitos com os franceses na disputa pela ocupação do território, ao longo da história ocorreram outros conflitos que causaram o extermínio de indígenas, a batalha com os holandeses e a invasão ao Quilombo dos Palmares. 
A instituição das capitanias hereditárias ocorreu quando Dom João III as instituiu em 24 de outubro de 1534. A capitania de Pernambuco possuía uma extensão de 60 léguas de terras, situadas entre o Rio São Francisco e o de Santa Cruz de Itamaracá, incluindo nos seus domínios o território de Alagoas (VERÇOSA, 2006). A doação de terras iniciou com a denúncia da existência de terras não ocupadas. Para Diégues Júnior (2012, p. 88) foi através da "carta régia de 20 de janeiro de 1699, a coroa se dirigia ao governador de Pernambuco, ordenando que qualquer pessoa que denunciasse a existência, em sesmarias, de terrenos incultos ou despovoados, fosse dada, sumariamente".

A extensão das terras dadas aos denunciantes era uma "área de três léguas de comprimento e uma de largura ou légua em meio em quadro" (DIÉGUES JÚNIOR, 2012, p. 88). As capitanias hereditárias "eram enormes faixas de terras que iam do litoral ao meridiano de Tordesilhas, entregues em forma de mercês aos capitães donatários, que não podiam vendê-las ou desmembrá-las, cabendo apenas ao Rei o poder de modificá-las ou excluí-las”. (STRAFORINI, 2008, p. 70 apud OLIVEIRA; SANTOS, 2014, p.83). Não eram totalmente ocupadas, apenas uma pequena parcela das terras era concedida aos donatários que não tinham a total posse dessas terras, estando subordinadas às ordens reais do rei de Portugal D. João III.

O excedente das terras era doado a quem o procurasse. Para Verçosa (2006) nas cartas de doação das sesmarias, era citada uma condição primordial para obter a concessão das terras: a instalação de engenho nas terras ocupadas. As capitanias eram divididas em sesmarias e doadas aos sesmeiros que tivessem posses e pudessem explorar o território, instalar engenho e formar povoado. "Havia algumas cujos limites eram os rios, já outras possuíam em torno de 32 mil quilômetros quadrados. Por essas dimensões, percebe-se o tamanho exageradamente grande da propriedade, onde a cana de Açúcar começou a ser cultivada" (LIRA, 2007, p. 11). Na época, a medida usada para medir as terras era em léguas uma capitania hereditária foi dividida em inúmeras sesmarias.

As terras de uma sesmaria eram divididas para criar outra sesmaria "ao repartir terras vão constituir outras sesmarias de menor porte, mas ainda assim imensas, além de fundar engenhos e levantar a povoação de Alagoas” (VERÇOSA, 2006, p. 40). Com essas doações, o território de Alagoas se expandiu, por conta do aumento na quantidade de terras usadas na 
plantação da cana-de-açúcar. "A atividade econômica influenciou na ampliação da ocupação de terras, sendo a pecuária mais percebida no interior do território, se afastando do litoral onde predominava a atividade agrícola do açúcar” (OLIVEIRA; SANTOS, 2014, p. 84). Haviam engenhos que logo deixaram de moer, porém, as terras continuavam a ser ocupadas.

A pecuária foi um dos fatores que levou os invasores a adentrarem ao sertão, como cultivo da cana era a meta principal, posteriormente a criação de gado tornou-se parte dos propósitos no uso das terras. Com a distribuição de terras, os sesmeiros passaram a ocupar o território sertanejo e as áreas próximas ao rio São Francisco eram propícias às pastagens e foram ocupadas pelos currais de gado, assim, as populações indígenas que ocupavam a região acabaram sendo dizimadas. Com isso, a ocupação alcançou o território da futura Mata Grande, que na época fazia divisa com Pernambuco e Bahia.

\section{A DISTRIBUIÇÃO E EXPLORAÇÃO DO TERRITÓRIO SERTANEJO}

Para o território da futura Mata Grande era visado à exploração das terras e a criação de gado, nessa sesmaria ocorreu várias subdivisões e as terras foram distribuídas para vários sesmeiros. Com a ocupação desse território surgiram fazendas que concentravam uma vasta extensão de terras, algumas dessas fazendas possuíam engenhos com a presença de escravos, nas quais os moradores plantavam alimentos que serviam para a sua subsistência, e logo depois foram surgindo às povoações. Como enfatiza Carvalho (2016, p. 20):

\footnotetext{
O sertão foi a última área a ser alcançada pela pecuária extensiva, que obteve grande êxito no semiárido. O ponto extremo do território - o futuro município de Mata Grande foi ocupado com a distribuição de sesmarias em 1658 e, no século seguinte, algumas de suas fazendas possuíam cerca de duas mil cabeças de gado e dezenas de escravos.
}

A doação de uma sesmaria deveria seguir a norma de doar somente para pessoas que fizessem o cultivo, porém, muitas vezes essa norma não era cumprida. Para conseguir uma doação bastava possuir o documento de doação feita pelo rei aprovando a apropriação do território. As pessoas que tinham ou não um título de nobreza recebiam as terras que seriam ocupadas. Os sesmeiros junto com outros membros de sua família possuíam várias sesmarias. Em muitas sesmarias, os proprietários recebiam as terras como doação, tendo de disputar cada quilômetro da propriedade com os indígenas que viviam nessa região. 
A distribuição das terras realizada pelos portugueses permitiu nesse período de estruturação da colônia, a instalação dos dois principais elementos produtivos. Os primeiros engenhos de açúcar, todos localizados na faixa litorânea, e as fazendas de gado que ocuparam o interior estabeleceram a economia da parte sul da Capitania de Pernambuco (CARVALHO, 2016). A expansão para o interior da capitania foi realizada através da criação de currais de gado, isso não foi menos latifundiária, pois a grande quantidade de terras era imprescindível para a pecuária (DIÉGUES JÚNIOR, 2012).

Os sesmeiros recebiam as sesmarias e costumavam deixar de herança para seus herdeiros parte dessas terras e em algumas situações essas terras eram vendidas. "Partilhado entre os herdeiros do proprietário, já porque este, em vida, separava um quinhão para o filho, construindo-lhe o engenho, já porque doações de outra natureza se fizeram, já mesmo pela venda de pedaços de terras para satisfazer compromissos financeiros" (DIÉGUES JÚNIOR, 2012, p. 87). Com a divisão de parte das terras de uma sesmaria, uma parte era deixada para os herdeiros e o restante que não era ocupada, os proprietários recorriam à venda dessas propriedades, verdadeiros latifúndios estavam nas mãos de poucas famílias.

Os currais de gado se alastravam pela região do Rio São Francisco indo em direção à região mineira, o tamanho das sesmarias era enorme tanto que alguns proprietários desconheciam a extensão de suas terras (DIÉGUES JÚNIOR, 2012). Localizado entre as capitanias de Sergipe e de Pernambuco, o posicionamento geopolítico do Rio São Francisco causava bastante conflito, pois esse espaço era disputado pelas autoridades locais e régias que buscavam atender seus próprios interesses (CURVELO, 2011). Em Alagoas, os conflitos por cargos e terras aconteciam constantemente, assim a formação de um povoamento ajudava a controlar as invasões.

No decorrer do tempo, com o crescente número de habitantes, os povoados também foram sendo ampliados, desta maneira, os fazendeiros se mudaram para os povoados, que se transformaram no centro da vida política e comercial. "Nessas vilas também se instalaram, desde o século XVI, as missões religiosas dos jesuítas, dos franciscanos, dos beneditinos e dos carmelitas" (CARVALHO, 2016, p.18). Na falta de uma organização política sólida, começaram a surgir conflitos nesses territórios, os missionários eram chamados e por meio das ações catequéticas conseguiam apaziguar as hostilidades. 
As missões estabelecidas no século XVI passaram em 1706 a ser realizadas por várias ordens religiosas: carmelitas, beneditinos, capuchinhos e jesuítas. Inicialmente na área canavieira, os missionários organizavam os aldeamentos indígenas, realizavam a catequese e construíam capelas e igrejas, depois foram se expandindo por todo território na margem do São Francisco e pelos povoados (CARVALHO, 2016). Nesse sentido, as missões evangelizadoras, a solução dos conflitos e a construção das igrejas tiveram um papel importante na consolidação da vida social da comunidade. Madeira e Sampaio (2011, p. 110) mencionam que:

\begin{abstract}
A grande propriedade, assegurada pelo sistema das Capitanias Hereditárias, redundou na constituição do mandonismo rural, forma de poder alicerçada na sociedade patriarcal cuja expressão emblemática é a realidade dos sertões nordestinos. Nos ermos sertões, onde a lei se personificava no grande proprietário, a força do Estado se traduziu-nos séculos da Colônia e do Império na ação dos clãs familiares detentores de grande extensão territorial e na prática sócio-religiosa e cultural-educativa das diferentes ordens religiosas atuantes nesses espaços.
\end{abstract}

Responsáveis por introduzir no Brasil a religião católica, era uma prática corriqueira dos portugueses doarem terras para construção de igrejas. De acordo com Rosendahl (1996, p. 60 ), "os senhores ricos fundavam igrejas e doavam propriedades para seu sustento e como retorno, queriam assegurar o controle sobre elas". Os sesmeiros doavam terras para a Igreja Católica por devoção aos santos católicos, como também, pelo interesse em atrair pessoas para ocupar o território, com isso, podiam arrecadar com o pagamento de impostos.

A colônia portuguesa tinha o interesse em que a religião católica obedecesse as suas normas, assim a igreja deveria repassar o que fosse arrecadado para a Fazenda Real e custear as suas despesas. Os ouvidores eram responsáveis por administrar a justiça na capitania, não recebiam pagamento, suas despesas eram custeadas pelos impostos que a Fazenda Real arrecadava. "A comarca não possuía capacidade para criar tributos. Todas as receitas pertenciam à Fazenda Real, e os impostos cobrados na colônia eram enviados para o Rio de Janeiro ou diretamente para Lisboa" (CARVALHO, 2016, p. 112). Com isso, a igreja e os administradores deveriam se submeter aos interesses de Portugal.

A construção de igrejas ajudava a semear a fé católica, contribuía na fixação dos novos povoamentos e na arrecadação financeira para custear as despesas da colônia. Corrêa (2011, p. 195) afirma que "a religião só se mantém se sua territorialidade for preservada e neste sentido, pode-se acrescentar que é pela existência de uma religião que se cria um 
território e, é pelo território que se fortalecem as experiências religiosas ou individuais". O catolicismo era a religião oficial do império, o ato de doar terras para a igreja mantinha a boa relação dos doadores com a coroa portuguesa, além de enraizar a religião dos seus antepassados no território conquistado.

Os portugueses tinham o costume de nomear suas conquistas, os lugares e os rios, de acordo com as datas religiosas. As ações missionárias e a devoção aos santos católicos foram sendo incorporadas nos povoados, inspirava na escolha do santo padroeiro para igrejas e capelas, gerando o aumento do número de adeptos e enraizando a devoção. "A ação católica nas suas mais diversas formas de manifestação teve um efeito profundo na formação do povo brasileiro" (HERCULANO; SANTOS, 2011, p. 44). As pessoas que se declaravam adeptos da religião católica eram mais aceitos pelos portugueses, diante disso:

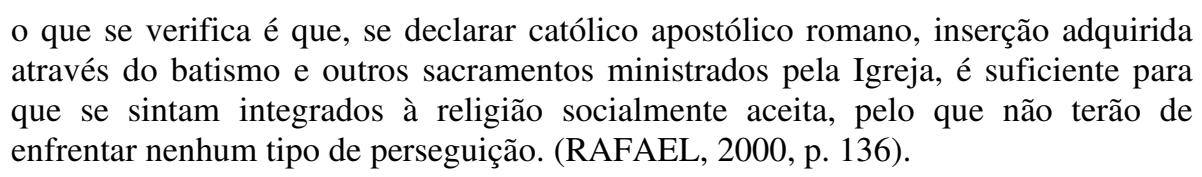

Ao receber os sacramentos da iniciação cristã como batismo, primeira eucaristia e crisma significava que as pessoas, já estavam integradas socialmente na religião católica. As festas religiosas, as novenas e as procissões contribuíram para a construção da territorialidade religiosa. Para Corrêa (2011, p. 251), "a territorialidade, por sua vez, refere-se ao conjunto de práticas e suas expressões materiais e simbólicas são capazes de garantirem a apropriação e permanência de um dado território por um determinado agente social”. A formação do povoamento, a construção de uma igreja simbolizava a apropriação e a permanência nas terras.

Sobre a ocupação do território alagoano, Carvalho (2016, p. 17) menciona:

O século XVII ficou marcado por dois movimentos significativos para a economia
local: a ampliação dos engenhos na zona da mata e a chegada da pecuária do sertão,
que aconteceu nos anos iniciais. Depois, no final do século, os portugueses
ocuparam o espaço palmarino; este foi distribuído por dezenas de sesmarias,
entregues principalmente aos militares que participaram da guerra contra a
insurreição liderada pelos antigos escravos africanos, concluindo assim, a ocupação
do atual território de Alagoas.

Em 13 de julho de 1822, a concessão de terras é suspendida por D. Pedro I, segundo Treccani (2001, p. 59): no "Brasil o regime de sesmaria foi suspenso em 1822" a organização e o uso da área territorial não tinham um controle. Com o interesse de manter o poder político 
e a ordem nas províncias, foi criada no período imperial em 1831 a guarda nacional que durou mais de noventa anos. Os fazendeiros e senhores de engenho que pertenciam à política alagoana, costumavam fazer parte da guarda nacional e obtinham cargos importantes como o de coronel, por exemplo.

A doação de terras e a distribuição de títulos "essa verdadeira institucionalização do poder privado, junto com as prebendas e os títulos de nobreza concedidos pelo governo imperial, irão, no dia-a-dia da província trazer um aumento descomunal do poder dos senhores rurais que irá se concentrar em algumas poucas famílias" (VERÇOSA, 2006, p. 67). Alagoas possuía centros políticos fortes que influenciavam nas decisões políticas do litoral ao sertão, essa base política estava restrita a poucas famílias: a oligarquia ruralista.

O coronelismo foi uma prática que contribuiu para que a oligarquia ruralista permanecesse por décadas no poder, comandando a política. A família Malta, natural de Mata Grande, dominou o Estado de Alagoas por doze anos. Em 1908 essa oligarquia mudou a jurisdição de Pão de Açúcar para Mata Grande. O governo dos Malta foi responsável por vender grandes extensões de terras públicas para os latifundiários, e as terras alagoanas negociadas com o setor privado beneficiando os senhores de engenho, políticos e ricos empresários.

Desta maneira, a má distribuição fez perpetuar no Estado a pobreza, já que os pobres não tinham quase onde plantar. Lira $(2007$, p. 17) expõe que o "resultado da má distribuição da propriedade da terra, iniciada a partir das sesmarias e fortalecida com a lei de terra de 1850, que só permitiu a posse da terra através da compra ou herança”. O governo dos Malta foi substituído, mesmo assim, a situação alagoana não teve muitos avanços. As terras alagoanas, em sua grande parte, estavam ocupadas pelas plantações da cana de açúcar, no qual muitas árvores foram derrubadas e pequenos proprietários tiveram suas terras invadidas.

A monocultura da cana de açúcar foi a responsável pela redução da plantação agrícola, gerando a escassez de alimentos básicos, como o feijão e a farinha. O Estado comprava produtos agrícolas de outras regiões, para suprir as necessidades da população. Se a situação da parte desenvolvida do Estado passava por privações, as condições de vida dos sertanejos também eram precárias. Os sertanejos produziam quase que só para o seu consumo, afastado 
da capital o deslocamento era dificultado pela falta de transportes, a falta de assistência na área da saúde refletia no número de óbitos, sendo superior ao número de nascidos.

\section{A DOAÇÃO DE TERRAS PARA O PATRIMÔNIO DA IGREJA CATÓLICA}

A ocupação do território matagrandense foi efetivado através da doação de terras para o patrimônio de Nossa Senhora da Conceição em 1791. Esse fato da doação de terras ocorreu antes da separação de Alagoas com Pernambuco em 1817. Como cita Carvalho (2016, p. 146): “em 16 de setembro de 1817, D. João VI assina o Alvará Régio no qual emancipa a Comarca de Alagoas". Portanto, o município sertanejo de Mata Grande localizado no Estado de Alagoas, no passado já fez parte da capitania pernambucana.

No dia 20 de junho de 1791 foi registrada uma escritura no cartório de Tacaratú que pertencia à capitania de Pernambuco. Nessa época, Alagoas ainda não tinha sido emancipada. Segundo o Livro de Tombo n² (1910 fls. 06), o documento foi feito por Francisco Gonçalves Teixeira e sua esposa Luiza Maria, doando uma parte das terras do Cumbe nas Matas de Santa Cruz, termo da vila de Penedo, comarca das Alagoas do Sul. O casal morador das Matas de Santa Cruz, motivados pela devoção fez a doação de terras para o patrimônio de Nossa Senhora da Conceição com a incumbência de ser construída uma capela.

Foi para o serviço de Deus e o bem comum dos católicos, que os responsáveis possuidores livres das terras, doaram um quarto de légua de terras em quadro, dentro das terras do Cumbe para patrimônio da capela. A doação de terras era um costume que os portugueses tinham de presentear as pessoas queridas, e o português Duarte Coelho também tinha esse costume de doar terras aos amigos. De acordo com Lira (2007, p. 16) "As sesmarias podiam ter dimensões ilimitadas. A partir de 1695, passaram a ter extensões máximas de 4 léguas de comprimento por uma légua de largura. No século XIX, passaram a ser de uma légua em quadrado”. Com o tempo as medidas de léguas sofreram diminuições:

Se pensarmos que uma légua corresponde hoje a 6 quilômetros (a légua de sesmaria correspondia a 6.600 metros), mesmo sem o conhecimento dos pontos geográficos que foram indicados como limites das sesmarias, dá pra imaginar a imensidão dos latifundiários que são outorgados oficialmente aos primeiros colonizadores que, por sua vez, irão subdividir seus domínios impossíveis de serem tocados como uma empresa única. (VERÇOSA, 2006, p. 40). 
As dimensões das sesmarias deixaram de serem ilimitadas em 1695, as demarcações passaram a possuir quatro léguas de comprimento por uma légua de largura, novamente no século XIX, os limites geográficos foram alterados para uma légua em quadrado. Com as alterações das medidas, o que antes era considerado como medida para légua passou a não ser, mesmo com as reduções das medidas, os sesmeiros tinham terras a perder de vista. Era tanta terra na mão de poucos donos, que se tinha o costume de arrendar algumas delas, vender ou doar.

Os primeiros sesmeiros da sesmaria Mata Grande receberam enormes extensões de terras. Com o tempo, as terras dessa sesmaria foram divididas com outros sesmeiros. Uma parte dessas terras que se encontrava nas terras do Cumbe, localizado nas Matas de Santa Cruz, no atual território chamado Mata Grande, doada por Francisco Gonçalves Teixeira e sua esposa Luiza Maria para a veneração de Nossa Senhora da Conceição. As terras da sesmaria Mata Grande doadas para Nossa Senhora da Conceição possuíam a extensão de um quarto de légua de terras em quadrado, sendo mais que suficiente para construir a capela.

Transferido o domínio das terras para o patrimônio da capela, os doadores pediam que os rendimentos que podiam ter dentro das terras, deviam ser cobrados e entregues ao tesoureiro ou aos responsáveis por administrar a capela. Os doadores tiveram a preocupação de deixar documentada a doação, para que, no futuro nem familiares ou outras pessoas interessadas pudessem recorrer da doação e alegar o pertencimento na justiça. Na Escritura de Doação apud Livro de Tombo (PARÓQUIA NOSSA SENHORA DA CONCEIÇÃO, nº 02 , fls.06) consta que:

Todos os rendimentos dos foros que se tenham dentro do dito quadro de léguas das terras para o prefixo patrimônio da capela de Nossa Senhora da conceição que sejam anualmente cobradas e entregues ao tesoureiro ou fabriqueiro que exerce para tudo o juramento ou que for preciso na dita Igreja, dizem ambos os doadores que assim querem por ser de livre espontânea vontade e que de hoje em diante transfere todo o poder e domínio que lhes tem quarto de légua das terras do Cumbe.

Por anos, as terras ficaram abandonadas, os superiores da Igreja Católica reclamavam por não ter uma pessoa designada a administrar e organizar o patrimônio. Em uma parte das terras doadas foi construída uma capela de taipa e em frente erguida uma cruz feita de madeira de uma enorme árvore chamada Maçarandubeira, segundo o Registro Paroquial (2010, p. 04). Mais tarde, a árvore serviu de referência para a escolha do nome da cidade de Mata Grande. A localização da capela se situava onde hoje se encontra a casa da senhora 
Lourdes, vizinha a Escola Estadual Demócrito Gracindo, na Rua Eustáquio Malta de Sá. Na época, havia um cemitério e por isso era chamada rua da Cruz.

O local em que situava a capela de taipa estava na parte baixa do terreno, com a ação dos fenômenos naturais, as fortes chuvas acabaram destruindo a capela. Diante dessa situação, houve a necessidade de construir uma nova capela, em um lugar que não sofresse danos e que suportasse as intempéries do clima. Isso é justificado com os relatos de Andrade (2011, p. 45) sobre as condições atmosféricas:

Os ventos que sobem do vale do São Francisco e as regiões aplainadas vizinhas transportam umidade até atingir serras como as de Mata Grande e Água Branca, localizadas muito no interior. Daí ser o Sertão alagoano, de modo geral, bem mais úmido do que o Sertão pernambucano, paraibano, norte rio-grandense, cearense ou baiano, e ser Alagoas, por dispor de menor área semiárida e oferecer, em geral, melhores condições à agricultura do que as semiáridas dos outros Estados nordestinos.

O município de Mata Grande está localizado no extremo NW do estado de Alagoas, está inserido numa microrregião serrana pertencente à mesorregião do sertão alagoano. $\mathrm{O}$ município também faz parte de duas unidades geoambientais: a Depressão Sertaneja na parte sul, com divisa a Inhapi e o Planalto da Borborema na parte norte do estado, com divisa a Pernambuco. Limita-se ao norte com os municípios de Manari e Inajá (PE), ao sul com Inhapi ao leste com Canapi e a oeste com Água Branca em Alagoas. A população estimada, de acordo com o IBGE em 2020, é de 25.207 habitantes, a área da unidade territorial de $908,3 \mathrm{~km}^{2}$. Desta maneira,

\begin{abstract}
A sede municipal de Mata Grande (AL) está localizada entre $09^{\circ} 07^{\prime} 06^{\prime \prime}$ de latitude sul e $37^{\circ} 44^{\prime}$ 04" de longitude oeste de Greenwich, situada numa altitude de 633 metros. O clima é tropical semiárido, com chuvas de verão. O período chuvoso se inicia em novembro com término em abril, com precipitação média anual de 431,8 $\mathrm{mm}$. A vegetação natural é caatinga hiperxerófila, apresentando alguns trechos com floresta caducifólia, sendo encontrada ainda a caatinga hipoxerófila em alguns pontos da área. (PARAHYBA, 2007, p. 1).
\end{abstract}

A região serrana de Mata Grande possui um relevo suave ondulado e clima tropical semiárido. Com precipitações chuvosas, a mudança da capela foi motivada pela incidência de alagamentos nos terrenos baixos. A nova capela foi construída em uma parte alta do terreno localizada na Praça Nossa Senhora da Conceição. O motivo dos doadores escolherem Nossa Senhora da Conceição está explícito na certidão: a doação das terras foi em prol da construção da capela. $\mathrm{O}$ gesto de doar demonstra o interesse de propagar a devoção à santa e consolidar o catolicismo no território matagrandense. 


\section{DESMEMBRAMENTOS OCORRIDOS NA PARÓQUIA DE MATA GRANDE (AL)}

A sesmaria Mata Grande, em 18 de março de 1837, além de freguesia (Paróquia), foi elevada à categoria de vila. Todo o território denominado de Mata Grande passa a fazer parte oficialmente da Paróquia de Nossa Senhora da Conceição. A partir do momento em que foi criada a freguesia (Paróquia) de Mata Grande, essa deixou de fazer parte da paróquia de Porto da Folha (Traipú), porém, ainda pertencia à diocese de Olinda (PE). O território paroquial de Mata Grande (AL) era extenso, na época abrangia todo o território que hodiernamente situa-se em Pão de Açúcar, Piranhas, Olho d'Água do Casado, Água Branca, Delmiro Gouveia, Pariconha, Inhapi e Canapi. O mapa da (figura 1) ilustra os territórios que foram desmembrados do território denominado de Mata Grande, quando foram criadas as suas paróquias.

Figura 1: Mapa do desmembramento do território denominado Mata Grande (1853-1976)
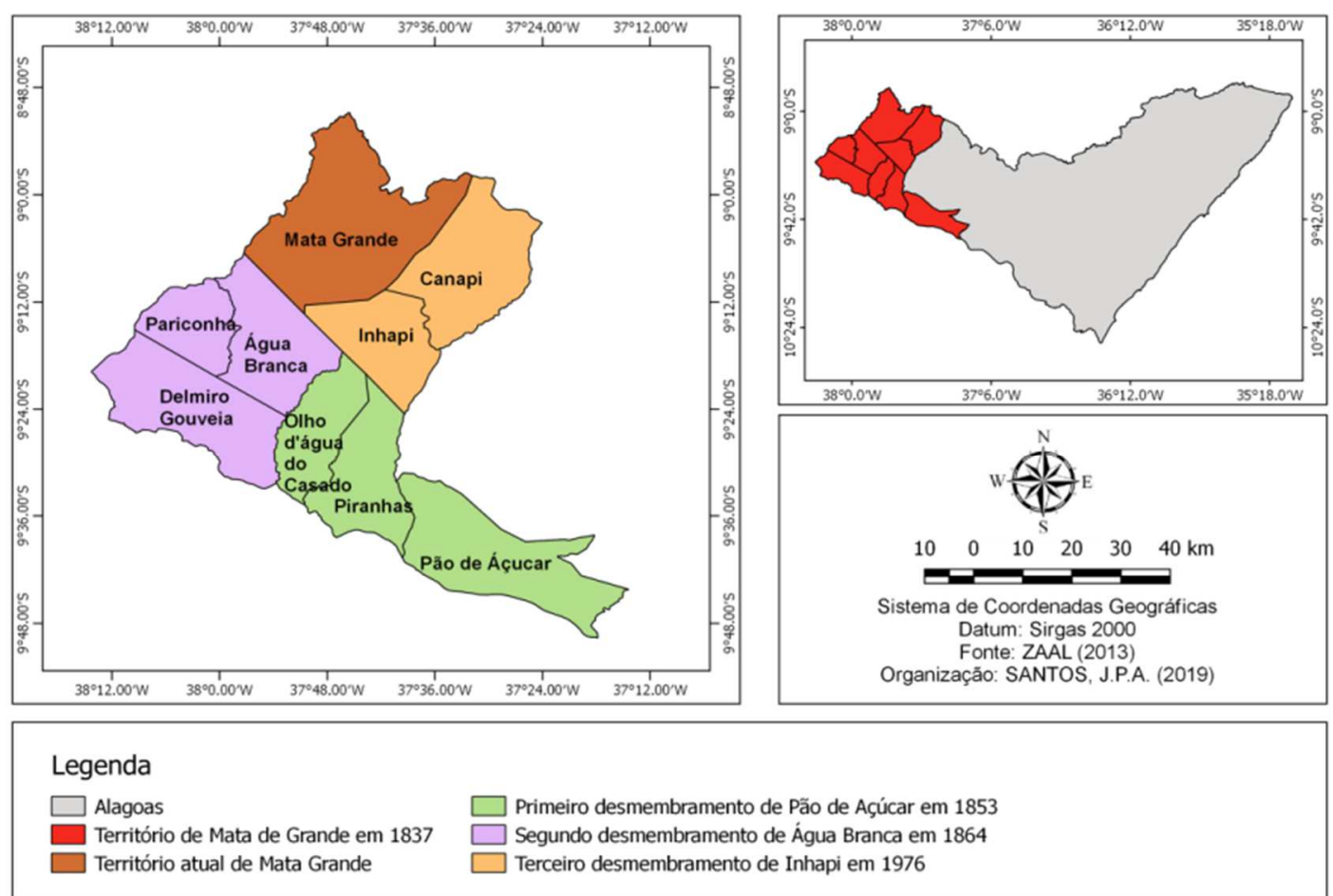

Fonte: ZAAL (2013). Elaboração Cartográfica: SANTOS, J.P. A (2019). 
$\mathrm{Na}$ época, as capelas e as igrejas que existiam nesse território, por questões burocráticas e eclesiásticas faziam parte da paróquia matagrandense. As terras doadas para a igreja pelo casal Francisco Gonçalves Teixeira e Luiza Maria não abrangia todas as terras da sesmaria Mata Grande. Existiam as subdivisões das terras, as que pertenciam a vários sesmeiros e as que foram doadas para a igreja. Então, o território ficou dividido em terras doadas para o patrimônio de Nossa Senhora da Conceição localizada na atual Mata Grande e as terras que pertenciam aos sesmeiros. Todas as terras estavam dentro do mesmo território paroquial e juntas formavam a sesmaria Mata Grande. O IBGE (2017) também faz menção a esse fato, a respeito das informações referentes à criação da vila e da freguesia de Mata Grande:

Elevado à categoria de vila com denominação de Mata Grande, pela lei provincial no
18, de18-03-1837, desmembrado de Porto da Folha (mais tarde Traipú). Pela lei
provincial no $\mathrm{n}^{\circ}$ 43, de 04-05-1846, a vila é extinta. Elevado novamente à categoria de
vila com a denominação Mata Grande, pela lei no 197 , de 28-06-1852. Reinstalada
em 27-09-1852. Pela lei provincial ${ }^{\circ}$ 516, de 30-04-1860, Mata Grande passou a
denominar-se Paulo Afonso. Elevado à condição de cidade com a denominação de
Mata Grande, pela lei estadual no ${ }^{\circ} 328$, de $05-06-1902$. Em divisão admintrativa
referente ao ano de 1911 , o município de Paulo Afonso é constituído do distrito
sede. Pela lei estadual no 1144 , de 25-05-1929, o município de Paulo Afonso passou
a denomina-se Mata Grande.

Elevada à vila e paróquia, "a província das Alagoas: no ano de 1838 já estava inteiramente povoada, inclusive no alto sertão, onde foi criada a vila de Mata Grande" (VERÇOSA, 2006, p. 70). O território denominado Mata Grande, na época fazia limite com Pão de Açúcar, em 11 de julho de 1853, sendo criada a paróquia de Pão de Açúcar, o que ocasionou o seu desmembramento do território paroquial de Mata Grande e diminuiu a extensão territorial. O território de Mata Grande, também limitava-se com a fazenda do Espírito Santo, atualmente conhecida como Inajá (PE), localizada na margem do rio Moxotó, daí abaixo até a fazenda Serra Branca, onde se limita com a freguesia de Água Branca (AL).

Espíndola (1871, p. 161-162 apud NUNES, 2010, p. 19) menciona alguns dados sobre os limites:

[A freguesia de Mata Grande] limitava com a freguesia de Pão de Açúcar pelo riacho Cabaços a começar na fazenda da Branquinha e de riacho acima até encontrar o riacho Capiá, que a separa da freguesia da Sant Ana e seguindo esse riacho até a sua cabeceira onde limitava-se com Pernambuco, deste ponto segue rumo direto à fazenda do Espírito Santo (atual Inajá), na margem do Moxotó e daí riacho a baixo até a fazenda Serra Branca, onde limita-se com a freguesia de Água Branca e dessa serra rumo direto para a nascente a sair na Branquinha. A sua sede dista de Pão de Açúcar 18 léguas ou pouco menos e 6 de Água Branca. 
Em 02 de junho de 1864 foi criada a paróquia de Água Branca, fato que provocou o seu desmembramento do território paroquial de Mata Grande, na época chamada Paulo Afonso. Portanto, Costa e Cabral (2016, p. 201) relatam que “em 1875 pela Res.n 681 de 24 de abril, sendo criada a comarca de Pão de Açúcar, cujo termo foi desmembrado de Paulo Afonso, passou a pertencer a esta o da nova Vila, que a mesma Resolução criou na povoação e freguesia de Água Branca”. Com o desmembramento, o padre da paróquia de Mata Grande estava incumbido de realizar apenas as funções pastorais dentro dos limites da sede matagrandense.

Relatos de 1871 identificam as atividades paroquiais realizadas em Mata Grande, indicando o quantitativo de sacramentos conforme Espíndola (1871) citado por Nunes (2010, p. 20): “foram entre 120 e 130 por ano, os casamentos foram 20 e os óbitos entre 16 a 20. Mata Grande possuía três capelas filiais: Santa Cruz do Deserto, a capela na Serra do Echú e a da Divina Pastora de Capiá”. Com o crescimento das povoações, a freguesia passou a ter 6.040 habitantes, sendo 5.484 livres e 556 escravos, o que intensificou as práticas agrícolas e a criação de animais.

Com a criação do Bispado de Alagoas, em 1900, a igreja de Alagoas foi desmembrada da diocese ${ }^{1}$ de Olinda. Na época, já havia 34 paróquias, com 225 igrejas para atender aos 511.440 habitantes, entre elas estava a paróquia de Nossa Senhora da Conceição em Mata Grande (NUNES, 2010). A sede episcopal passou a ser na cidade de Maceió, como Olinda ainda não era arquidiocese, a recém-criada diocese das Alagoas passou a fazer parte da arquidiocese de Salvador na Bahia.

Em 1916 ocorreu a criação da diocese de Penedo, a paróquia de Mata Grande muda da diocese de Maceió e passa a fazer parte da diocese de Penedo de 1918 até 1962. Em 10 de fevereiro de 1962, foi fundada a diocese de Palmeira dos Índios, localizada no agreste do território alagoano e como era a mais próxima do sertão, a paróquia de Mata Grande passou a pertencer à diocese de Palmeira dos Índios. Com o desmembramento das outras paróquias atualmente apenas, o município de Mata Grande faz parte do território paroquial da Igreja Matriz de Nossa Senhora da Conceição.

${ }^{1}$ Cân. 369 - A diocese é a porção do povo de Deus que é confiada ao Bispo para ser apascentada com a cooperação do presbitério, de tal modo que, aderindo ao seu pastor e por este congregada no Espírito Santo, mediante o Evangelho e a Eucaristia, constitua a Igreja particular, onde verdadeiramente se encontra e atua a Igreja de Cristo una, santa, católica e apostólica. (CÓDIGO DE DIREITO CANÓNICO, 1983, p. 67). 


\section{OS LIMITES DO PATRIMÔNIO PAROQUIAL DE MATA GRANDE (AL)}

A doação das terras e a construção da igreja foram ações importantes que contribuíram para o crescimento da comunidade matagrandense e efetivou o reconhecimento desse território. "a posse do território é seguida de um ritual que simboliza o ato da criação. $\mathrm{O}$ território é ocupado e dessa forma, consagrado, protegido e reconhecido pela comunidade"

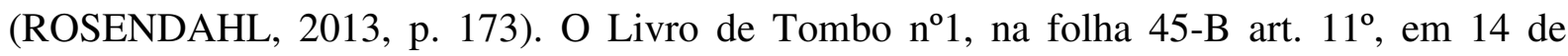
novembro de 1886, relata que a freguesia nem por si nem por interposta pessoa poderia sem autorização competente comprar, permutar, arrendar ou aforar, os bens de qualquer natureza pertencentes ao patrimônio da igreja.

As terras do patrimônio foram sendo ocupadas de forma irregular, pois, não era permitida a venda sem autorização da igreja. O documento da doação de 1791 não informava os limites das terras doadas à igreja, apenas constava a quantidade das terras. A falta de demarcação das terras causava constantes confusões, durante mais de cem anos, as terras foram sendo ocupadas sem os limites definidos. $\mathrm{O}$ visitador padre Jonas de Araujo Batista, ao visitar a paróquia de Nossa Senhora da Conceição em 20 de fevereiro de 1896, determina a demarcação das terras do patrimônio pelos limites conhecidos para evitar dúvidas futuras, garantindo assim, o que pertence à igreja.

Nas folhas 170 e 171 do Livro de Tombo n ${ }^{\circ} 1$ consta que no dia 21 de maio de 1900, o padre Manoel Firmino Pinheiro da vila de Mata Grande, resolveu em acordo com os proprietários os limites do patrimônio. Lavrado e reconhecido como legítimos todos os marcos, cuja área mede um quarto de largura em um quadro no terreno. Porém, no dia 14 de agosto de 1939, segundo o Livro de Tombo n² (1939, p. 3-B), o padre Dumouriez constatou que os arquivos da paróquia estavam incompletos, além de não encontrar a certidão de demarcação das terras, faltava o livro número nove com importantes documentos, casamentos, batizados, óbitos e crisma.

O livro sumiu na época em que o padre Manoel Firmino Pinheiro estava na paróquia. O fato do padre Manoel Firmino Pinheiro em 1900 ter entrado em acordo com os proprietários dos terrenos que estavam nas terras do patrimônio ou faziam limites para fazer a 
demarcação, poderia ter sido a motivação do sumiço do livro. O padre Dumouriez Monteiro do Amaral registrou no Livro de Tombo $\mathrm{n}^{\circ} 2$ na folha 05-B e 06-A, nos dias 14 e 16 de fevereiro de 1940, a vontade de regularizar os negócios do patrimônio.

Conseguiu com um proprietário das terras vizinhas as da paróquia, uma cópia autêntica da escritura do patrimônio feita em 1900, pelo padre Manoel Firmino Pinheiro. Como o termo de demarcação não estava homologado em cartório, o padre Dumouriez aceitou o registro com o termo amigável, pois, o documento não foi assinado pela maioria dos proprietários e cujas propriedades faziam limites com as terras da paróquia. Sem esse termo, o documento não tinha valor jurídico e, por não possuir documento comprobatório, a paróquia corria a risco de perder as terras.

De acordo com a certidão de registro do imóvel, consta-se que as terras pertencentes ao patrimônio de Nossa Senhora da Conceição na cidade de Mata Grande. Adquirido por escritura de doação em 22 de fevereiro de 1940 pelo termo de demarcação amigável em 08/junho/1940. Os limites do patrimônio foram demarcados por 29 marcos de pedras e estacas de aroeira, grafadas com as iniciais (N.S), com o auxílio de balizas seguiam marcando toda a extensão das terras. As medidas e as referências usadas para a demarcação não são seguras com o tempo podem ter sofrido alterações. A respeito da demarcação de terras, pode-se compreender que:

Partindo da Cachoeirinha atravessa o caminho do mandacaru de baixo, e junto ao cercado de Antonio Rodrigues ao pé de uma cajarana, se coloca o primeiro marco, segue a nascente até a propriedade Cajazeiras, finca outro marco e mais outros setes, limitando toda está extensão. Ao Sul com David Gomes de Sá o único proprietário limite, estabelece uma linha provisória, entre o patrimônio e a propriedade Cajazeira, segue rumo direto, para o Pau d'alho do caminho dos tocos, estabeleceram os limites do patrimônio. Ao nascente, com demais terrenos limites, dos proprietários Ezechiel Izídio de Souza e Pedro Izídio de Sousa, do Pau d'alho do caminho dos tocos, segue para o sítio de Maria Casemiro. Ao nascente, com as terras da pipa no sítio de Maria Casemiro, segue rumo ao poente até a estrada, que vai para Mata Grande, do lado direito da estrada segue até a fonte do professor, seguindo para o poente pela baixa da Januária, e na estrada que desce para o Cumbre, foram colocados marcos de pedra e uma estaca de aroeira. (CERTIDÃO DE REGISTRO, 1940).

Verifica-se que a doação das terras feita em 1791 por Francisco Gonçalves Teixeira e Luiza Maria ao patrimônio de Nossa Senhora da Conceição, levou mais de cem anos após a doação para ser demarcada. Em 1900, o padre Manoel Firmino Pinheiro fez a demarcação e demarcou os limites de acordo com a extensão de um quarto de légua de terras em quadrado. 
Porém, somente em 1940 a certidão das terras do patrimônio foi registrada pelo padre Dumouriez no cartório de Mata Grande para que não restassem dúvidas sobre os seus limites e a legitimidade da doação. Depois desse registro, a paróquia não fez mais nenhuma atualização dos limites das terras do patrimônio, deste modo, a paróquia não tem o controle das terras e a doação é praticamente simbólica.

Em 2005, o município de Mata Grande aderiu ao programa do governo que regularizava as propriedades de pessoas de baixa renda. Para comprovar que os terrenos não estavam dentro do patrimônio paroquial, o governo em parceria com outros órgãos realizou um levantamento topográfico e fotográfico. O que possibilitou a produção do mapa de toda a área da cidade de Mata Grande. Com essas informações, elaborou-se a documentação das propriedades que não fazem parte do patrimônio paroquial.

A partir do levantamento topográfico de 2005, fez-se uma atualização dos marcos que foram realizados na época da demarcação, em 1900. Através dessas informações, também foi possível fazer o mapa das terras do patrimônio da paróquia de Nossa Senhora da Conceição tal mapeamento permite uma noção da área ocupada. O mapa do patrimônio da paróquia de Mata Grande (AL) mostra que o primeiro ponto, tem como referência a ponte do Mandacaru (bairro localizado na entrada da cidade), depois segue à direita em direção sul, onde está localizada a vila da Cohab do Mandacaru.

Seguindo para o segundo ponto localizado no sítio Cajazeira, indo em direção ao leste encontra-se o terceiro ponto que faz limite com Manoel Barbosa Silva, continuando na direção leste, encontra-se o quarto ponto o Pau D'alho Velho. Rumo em direção ao norte, o quinto ponto está localizado no Bonsucesso, seguindo para a praça do Colosso, no qual se localiza o sexto ponto e, indo para o oeste, na rua Dr. Dumouriez Monteiro do Amaral são demarcados dez pontos. (REGISTRO DE DEMARCAÇÃO, 2005).

Conforme podemos observar na (figura 2) o Mapa do patrimônio da paróquia² de Mata Grande (AL):

\footnotetext{
${ }^{2}$ Cân. $515-\S 1$. A paróquia é uma certa comunidade de fiéis, constituída estavelmente na Igreja particular, cuja cura pastoral, sob a autoridade do Bispo diocesano, está confiada ao pároco, como a seu pastor próprio. (CÓDIGO DE DIREITO CANÓNICO, 1983, p. 95).
} 
Figura 2: Mapa do Patrimônio da paróquia de Mata Grande (AL)

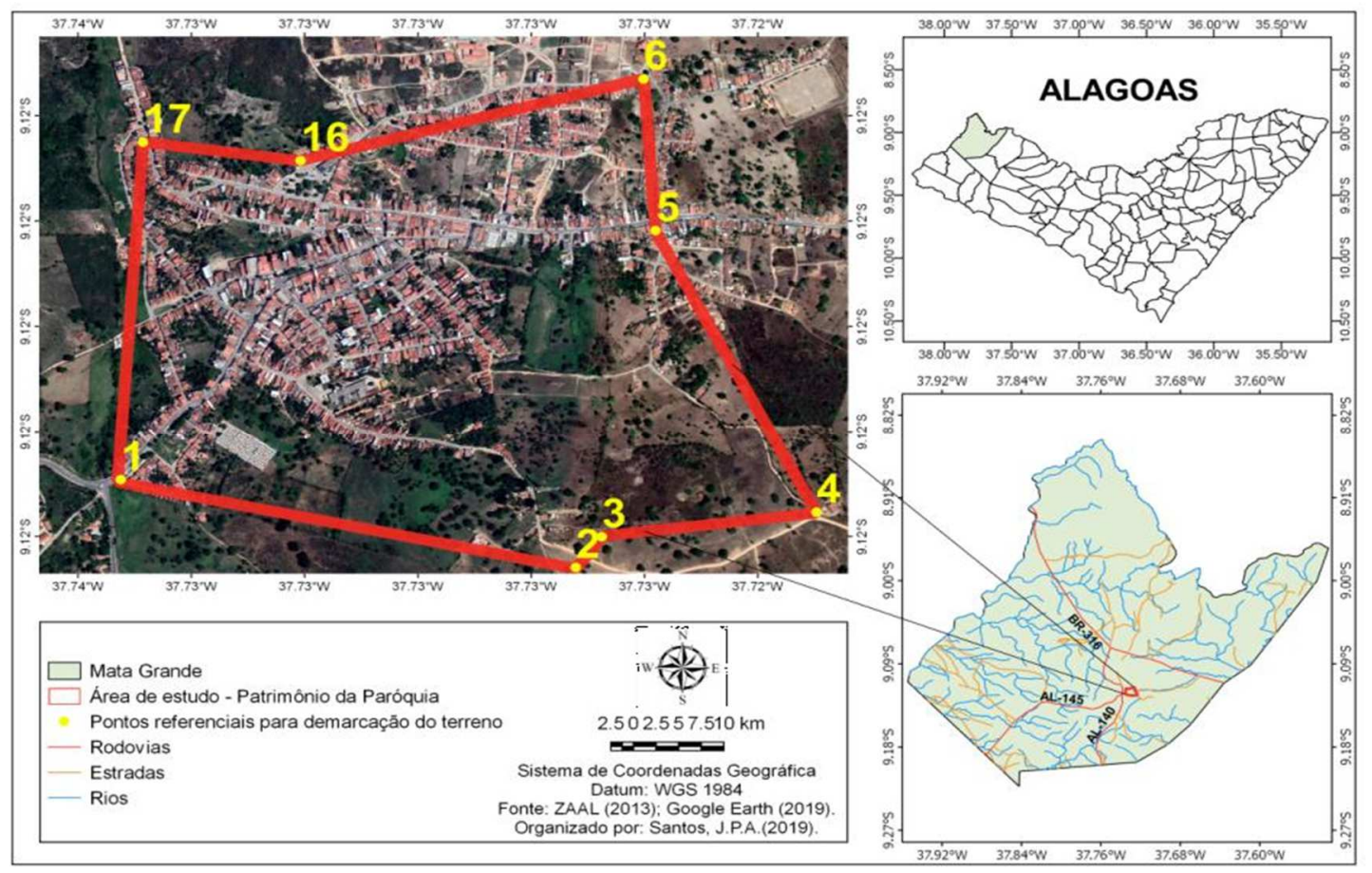

Fonte: ZAAL (2013). Elaboração Cartográfica: SANTOS, J. P.A (2019).

Ainda pode ser observado que o mapa a que se refere à (figura 2), as ruas do ponto dezesseis não estão especificadas, assim, segue para o ponto dezessete com a referência do depósito de gás do Ginaldo, novamente não se usa as ruas como referência, indo em linha vertical para o sul, encontra o ponto inicial, a ponte do Mandacaru. Concluiu-se também que os nomes dos vizinhos das terras do patrimônio, não são mais os mesmo que estão na certidão de registro de 1940. Conforme o mapeamento de 2005, o patrimônio de Nossa Senhora da Conceição possui atualmente uma área de 103.320.9 Hectares (ha) ou 341.556.7 Tarefas de terras, todas as ruas que estão dentro dessa extensão são do patrimônio.

A rua da Matriz está localizada dentro da área do patrimônio, mesmo assim, tanto nessa rua como em outras existem algumas residências que não mais fazem parte do patrimônio, pois há pessoas que buscaram a isenção do patrimônio realizando uma declaração nos órgãos municipais, como se os terrenos fossem públicos. Cabe ressaltar que os doadores das terras expressaram no documento de doação o desejo de que as pessoas ocupantes das terras fizessem uma contribuição para a igreja. Assim, de acordo com as medidas de cada terreno, a paróquia cobra uma pequena taxa à população pela ocupação das suas terras, porém nem sempre contribuem com o pagamento da taxa. 


\section{CONSIDERAÇÕES FINAIS}

O território de Mata Grande passou por vários processos históricos e geográficos. O motivo dos doadores escolherem Nossa Senhora da Conceição está explícito na certidão, a doação das terras foi em prol da construção da capela e da veneração a Nossa Senhora da Conceição. O gesto de doar demonstra o interesse de propagar a devoção à santa e consolidar o catolicismo no território matagrandense. A priori, Mata Grande era uma sesmaria, segundo o Livro de Tombo $n^{\circ} 1$ (1920, p. 169) conseguiu ser elevada à vila e freguesia em 18 de março de 1837 .

Ocorreram vários desmembramentos no território paroquial de Mata grande, como a criação das paróquias de Pão de Açúcar em 1853, Água Branca em 1864 e Inhapi em 1976. Todos esses desmembramentos deixaram Mata Grande apenas com o território paroquial a que pertence seu município, a sua atual configuração tem a mesma extensão, o território municipal e paroquial é um só. Todas essas paróquias fazem parte da diocese de Palmeira dos Índios e a data da criação dessas paróquias é diferente da data de emancipação política desses municípios.

O seu território abrangia a cachoeira do rio São Francisco e que em 1870 passou a ser chamada de Paulo Afonso. Com a emancipação política de Água Branca, em 1875, Mata Grande perdeu o vínculo com a cachoeira do rio São Francisco. Em 1902, Mata Grande foi elevada à cidade, na época, o matagrandense Euclides Vieira Malta governador de Alagoas, preferiu manter o nome de Paulo Afonso, porém, em 1929 volta a ser chamada de Mata Grande.

A falta de organização da Igreja Católica deixou por muito tempo as terras do patrimônio de Nossa Senhora da Conceição sem demarcação. Muitas pessoas foram ocupando indevidamente as terras. Cem anos depois foi realizada a demarcação das terras, na tentativa de solucionar as situações de conflitos, entre a igreja e os ocupantes. A igreja não possuía o documento de doação, tampouco as terras estavam registradas em cartório, sendo um vizinho das terras que cedeu uma cópia do documento de doação. 
A paróquia teve que aceitar a condição de demarcação das terras paroquiais, com o termo amigável, caso contrário, não teria como registrar as terras e podia perdê-las. Grande parte do perímetro da cidade de Mata Grande está localizada em terras doadas para o patrimônio de Nossa Senhora da Conceição, porém, a igreja tem a posse das terras apenas no sentido simbólico, caso necessite terá que comprar as próprias terras ou recebe-lá como uma doação.

\section{REFERÊNCIAS}

ANDRADE, M.C. A terra e o homem no nordeste: contribuição ao estudo da questão agrária no Nordeste. 8. ed. São Paulo: Cortez, 2011.336 p.

BLOG DA DIOCESE DE PALMEIRA DOS ÍNDIOS (AL). Disponível em: <http://diocesedepalmeiradosindios.blogspot.com/>. Acesso em: 10 fev. 2019.

CARVALHO, C. P. Formação histórica de Alagoas. 2. ed.Maceió: Edufal, 2016.352 p. CÓDIGO DE DIREITO CANÔNICO, promulgado por João Paulo II, Papa. Conferência Episcopal Portuguesa. 4. ed. Braga: Apostolado da Oração, 2007. 504 p.

CORRÊA, R.L. Introdução à geografia cultural. CORREAA, R; ROSENDAHL, Z.L. (orgs.). 4. ed. Rio de Janeiro: Bertrand Brasil, 2011. 226 p.

COSTA, C.; CABRAL, T. Indicador geral do estado de Alagoas. Maceió: EDUFAL, 2016. $360 \mathrm{p}$.

CURVELO, A. Conflitos na Comarca: Disputas por jurisdição e controle político em Alagoas Colonial (1711-1758). In: CAETANO, A. F. P. (org.). Conflitos, revoltas e insurreições na América portuguesa. Maceió: Edufal, 2011. 200 p.

DIÉGUES JÚNIOR, M. População e açúcar no Nordeste do Brasil. 2. ed. Maceió: EDUFAL, 2012.236 p.

GIL, A. C. Como elaborar projetos de pesquisa. 4. ed. São Paulo: Atlas, 2002. 192 p. GOVERNO DE ALAGOAS. Perfil Municipal Ano 2014, n.2. Maceió: Secretaria de Estado do Planejamento e do Desenvolvimento Econômico, 2013. Disponível em:<http://www.seplande.al.gov.br>. Acesso em: 20 dez. 2018.

HERCULANO, E.O.; SANTOS, I. G. Capuchinhos Italianos no Nordeste Brasileiro: Uma trajetória de Sócio-Religiosa (Séculos XVIII-XIX). In: MADEIRA, M. G. L; SAMPAIO, W. C. (orgs.). Missionários e beatos nos Sertões Nordestinos: Ações socializadoras e formativas (séculos XVIII-XX). Maceió: Edufal, 2011. 160 p. 
IGREJA CATÓLICA. Código de Direito Canônico. Disponível em: http://www.vatican.va/archive/cod-iuris-canonici/portuguese/codex-iuris-canonici_po.pdf>. Acesso em: 13 fev. 2019.

LIRA, F. J. Formação da riqueza e da pobreza de Alagoas. Maceió: Edufal, 2007.320 p.

MADEIRA, M.G. L.; SAMPAIO, W. C. (orgs.). O Caldeirão de Zé Lourenço Missionários e beatos nos Sertões Nordestinos: Ações socializadoras e formativas (séculos XVIII-XX). Maceió: Edufal, 2011, p. 160.

NUNES, M.M.M. Dom Antônio Manoel de Castilho Brandão: Um bandeirante nas terras das Alagoas. Maceió. Edufal. 2010. 87 p.

OLIVEIRA, R. T.; SANTOS, K.S. O início da formação territorial brasileira: uma reflexão sobre o território em Suape. Revista de Geografia (UFPE). v. 31, n. 3,p.82-95, 2014.

PANORAMA ESTATÍSTICO DE MATA GRANDE (AL). Disponível em: <https://cidades. ibge. gov.br/mata-grande/panorama>. Acesso em: 13 fev. 2019.

PARAHYBA; LEITE, A. P. Solos do Município de Mata Grande. Estado de Alagoas. Rio de Janeiro: Embrapa Solos, 2007.

PARÓQUIA DE NOSSA SENHORA DA CONCEIÇÃO DE MATA GRANDE (AL). Livro de tombo no 1(1884-1938). Arquivo paroquial de Mata Grande (AL).

Livro de tombo $\mathbf{n}^{\mathbf{0}} 2$ (1938-2011). Arquivo paroquial de Mata Grande (AL).

Registro Paroquial (2010). Arquivo paroquial de Mata Grande (AL).

RAFAEL, U. N. Campo Religioso Alagoano. In: PEDROSA, T.M. (org.). Arte popular de Alagoas. Maceió: Grafitex, 2000. 217 p.

ROSENDAHL, Z. Espaço e religião: uma abordagem geográfica. 2. ed. Rio de Janeiro: Uerj, 1996. $89 \mathrm{p}$.

ROSENDAHL, Z.; CORRÊA, R. L. (orgs.). Geografia cultural: uma antologia. Rio de Janeiro: Eduerj, 2013. 406 p.

TRECCANI, G. Violência e grilagem: instrumentos de aquisição da propriedade da terra no Pará. Belém: Ufpa, 2001.600 p.

VERÇOSA, E.G. Cultura e educação nas Alagoas: histórias, histórias. 4. ed. Maceió: EDUFAL, 2006. 219 p. 